\title{
Biomass production and wheat grain yield and its relationship with NDVI as a function of nitrogen availability
}

\author{
Carolina Trentin ${ }^{1 *} \oplus$, Christian Bredemeier ${ }^{2} \odot$, André Luis Vian² ${ }^{\circledR}$, \\ Maicon Andreo Drum² ${ }^{\oplus}$, Franciane Lemes dos Santos² \\ ${ }^{1}$ Universidade de Passo Fundo, Passo Fundo, RS, Brasil. E-mail: carolinatrentin@live.com \\ ${ }^{2}$ Universidade Federal do Rio Grande do Sul, Porto Alegre, RS, Brasil. E-mail: bredemeier@ufrgs.br; andre.vian@ufrgs.br; maicon.a.drum@gmail.com; franciane_lemes@hotmail.com
}

ABSTRACT: Evaluate the ideal doses of nitrogen fertilizer on wheat crops, in addition to avoiding unnecessary costs, assists in sustainability of the production system. The objective was to evaluate the effect of nitrogen $(\mathrm{N})$ doses on the biomass and grain productivity, and the correlation between the normalized difference vegetation index (NDVI), biomass at flowering and grain yield, in wheat crop. The experiment was carried out in the experimental area of UFRGS, in Eldorado do Sul, in 2017 and 2018, under randomized block, with four replications. The treatments consisted of $\mathrm{N}$ doses at sowing $(0,15,30$ e $45 \mathrm{~kg}$ de $\mathrm{N}$ $\left.\mathrm{ha}^{-1}\right)$ and in topdressing $(2017-0,20,40,60$ e $80 \mathrm{~kg}$ de N ha-1 and $2018-0,40$ e $80 \mathrm{~kg}$ de N ha-1). The wheat cultivars BRS Parrudo and TBIO Toruk were used. The treatment with 30 and $45 \mathrm{~kg} \mathrm{de} \mathrm{N} \mathrm{ha}^{-1}$ applied at sowing combined with $80 \mathrm{~kg}$ de N $\mathrm{ha}^{-1}$ applied in topdressing, were those that obtained the highest yields of both grain and biomass, for both years and cultivars. The correlation between NDVI and biomass and grain yields were high for both years and cultivars.

Key words: biomass; Triticum aestivum L.; vegetation index; grain yield

\section{Produção de biomassa e rendimento de grãos de trigo e sua relação com o NDVI em função da disponibilidade de nitrogênio}

RESUMO: Avaliar as doses ideais de fertilizantes nitrogenados na cultura do trigo, além de evitar custos desnecessários, auxilia na sustentabilidade do sistema produtivo. $\mathrm{O}$ objetivo foi avaliar os efeitos de doses de nitrogênio ( $\mathrm{N}$ ) na biomassa e rendimento de grãos e na correlação entre o índice de vegetação por diferença normalizada (NDVI), biomassa no florescimento e o rendimento de grãos, na cultura do trigo. O experimento foi conduzido na área experimental da UFRGS, em Eldorado do Sul, nas safras de 2017 e 2018, sob delineamento de blocos casualizados com 4 repetições. Os tratamentos consistiam em

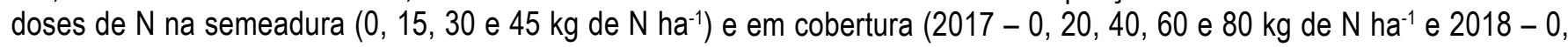
40 e $80 \mathrm{~kg}_{\text {de }} \mathrm{N} \mathrm{ha}^{-1}$ ). Foram utilizadas as cultivares de trigo BRS Parrudo e TBIO Toruk. Os tratamentos com 30 e $45 \mathrm{~kg} \mathrm{ha}^{-1}$ de $\mathrm{N}$ na base, combinados a $80 \mathrm{~kg} \mathrm{ha}^{-1}$ de $\mathrm{N}$ em cobertura, foram os que obtiveram maiores produtividades tanto de grãos como de biomassa, para ambas as safras e cultivares. A correlação entre o NDVI e as produtividades de biomassa e de grãos foram altas para as safras e cultivares.

Palavras-chave: biomassa; Triticum aestivum L.; índice de vegetação; rendimento de grãos

\footnotetext{
* Carolina Trentin - E-mail: carolinatrentin@live.com (Corresponding author)

Associate Editor: Henrique Pereira dos Santos
} 


\section{Introduction}

The no-till (NT) farming system has emerged as an alternative to decrease problems with greenhouse gas emissions, improve soil biological quality, and decrease erosion losses (Heroldová et al., 2017). One of the precepts for the use of NT is that the cultivation areas must always be kept with vegetation cover, besides the need to rotate species, such as legumes and poaceae, which tends to complement the availability of nutrients, such as nitrogen $(N)$, fixed by symbiont bacteria in soybeans. Thus, they make greater amounts of the nutrients available to poaceae, which require high amounts of $\mathrm{N}$ for high yield potential (Finney et al., 2016).

NT helps to increase productivity, especially in years with below-average rainfall, which occurs especially during soybean cultivation, and by increasing the biological quality of production areas (Kuhn et al., 2016).

Despite the improvement in nutritional availability and the increase in soil organic matter content with the adoption of SPD, the use of fertilizers, especially nitrogen fertilizers, is still fundamental and necessary for the development of poaceous species.

Nitrogen is an important nutrient for the production of enzymes and proteins that make up the photosynthetic system of plants, which result in the accumulation of photoassimilates, and in sequence is required for grain formation and filling (Leghari et al., 2016; Zörb et al., 2018). At wheat sowing, a partial dose of the fertilizer required by the crop is applied, and the rest is divided into top dressing applications during the stages of development in which the plants demand nitrogen the most, such as at tillering and the beginning of the stem elongation (Haun, 1973; Bredemeier \& Mundstock, 2001). This is because of the low requirement at the early stage and because it increases the risks of losses by leaching and volatilization, as well as causing salt stress since the fertilizer is applied at the seeding row (Dehnavi et al., 2020).

Fertilizer applications in crops mostly do not take into account the residual nutrient content in the soil and sometimes not even the actual need of the plant (Elsayed et al., 2018). However, the Liming and Fertilization Manual for the states of Rio Grande do Sul and Santa Catarina indicates that the use of nitrogen fertilizers should be based on the predecessor crop, the organic matter content of the soil, and the expected yield (CQFS - RS/SC, 2018).

Identifying the integrated effects of different combinations of $\mathrm{N}$ management is of fundamental importance in order to achieve high wheat grain yields with higher use efficiency of this nutrient (Lu et al., 2016). Therefore, the evaluation of the ideal doses of nitrogen fertilizers that wheat plants need, besides avoiding unnecessary costs for the producer, helps in the sustainability of the productive system, reducing the impacts caused by the excessive application of $\mathrm{N}$.

The objective of the present work was to evaluate the effects of nitrogen $(\mathrm{N})$ doses applied at sowing and top dressing on biomass production and grain yield and their correlations with the Normalized Difference Vegetation Index (NDVI) in wheat.

\section{Materials and Methods}

\section{Location and characteristics of the study area}

The experiments were carried out during the 2017 and 2018 agricultural seasons at the Agronomic Experimental Station of the Federal University of Rio Grande do Sul (EEA/ UFRGS), municipality of Eldorado do Sul, RS, Brazil. The experimental area is located in the physiographic region of the Central Depression of Rio Grande do Sul, with an average altitude of $46 \mathrm{~m}$ above sea level (homogeneous region of adaptation of wheat cultivars 2 - moderately hot and humid). The climate is Cfa, according to Koppen classification (IPAGRO, 1979). The average annual rainfall in Eldorado do Sul is 1440 $\mathrm{mm}$ and the average monthly air temperature varies between 14 and $25^{\circ} \mathrm{C}$ (Bergamaschi et al., 2003). The weather elements (monthly air temperature and cumulative precipitation) for the years 2017 and 2018 are shown in Figure 1. The soil is characterized as Dystrophic Ultisol (Streck et al., 2018), with approximately $2.0 \%$ of organic matter.

The experimental design used was a randomised block design in both crops, where each cultivar was conducted in separate trials. The wheat cultivars BRS Parrudo and TBIO Toruk and doses of $\mathrm{N}$ applied at plant emergence (base) and in top dressing at the stage of six fully expanded leaves were used (Haun, 1973).

In 2017, the experiment was composed of 20 treatments, with three repetitions. Each plot consisted of a total area of $4.5 \mathrm{~m}^{2}$, composed of 10 rows of $2.5 \mathrm{~m}$, spaced at $0.18 \mathrm{~m}$. In 2018, there were 12 treatments, with three repetitions for BRS Parrudo and four repetitions for TBIO Toruk, with each plot consisting of $5.4 \mathrm{~m}^{2}$, composed of 10 rows of $3 \mathrm{~m}$, spaced at $0.18 \mathrm{~m}$. The treatments were composed of a combination of base and top dressing $\mathrm{N}$ doses (Table 1 ), applied in the form

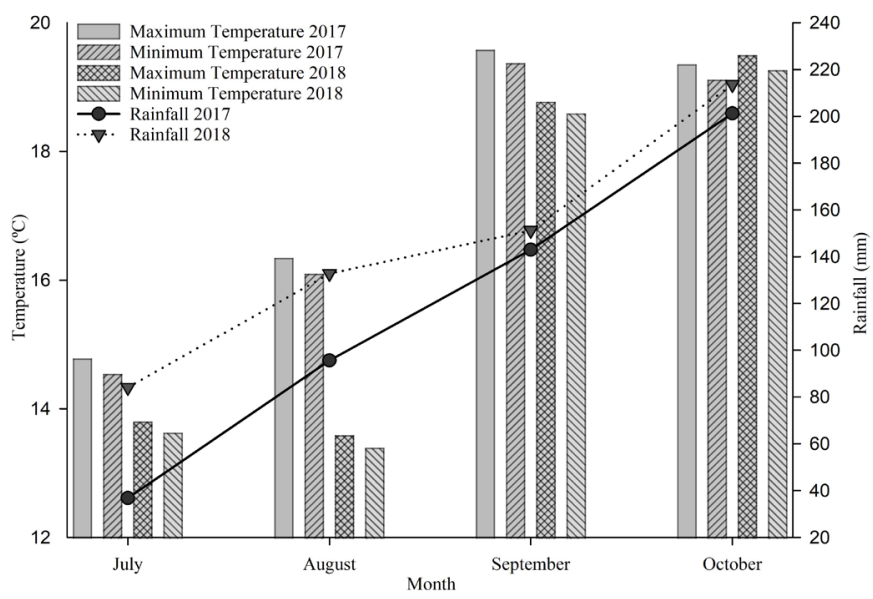

Figure 1. Maximum and minimum temperatures, and rainfall for the 2017 and 2018 seasons at the Agronomic Experimental Station of the Federal University of Rio Grande do Sul (EEA) UFRGS), Eldorado do Sul - RS, Brazil. 
Table 1. Treatments with nitrogen doses applied at plant emergence (base) and in topdressing in 2017 and 2018.

\begin{tabular}{|c|c|c|c|}
\hline \multicolumn{2}{|r|}{2017} & \multicolumn{2}{|r|}{2018} \\
\hline Base dose & Topdressing dose & Base dose & Topdressing dose \\
\hline \multicolumn{4}{|c|}{ kg ha-1 } \\
\hline \multirow{5}{*}{0} & 0 & \multirow{5}{*}{0} & 0 \\
\hline & 20 & & - \\
\hline & 40 & & 40 \\
\hline & 60 & & - \\
\hline & 80 & & 80 \\
\hline \multirow{5}{*}{15} & 0 & \multirow{5}{*}{15} & 0 \\
\hline & 20 & & - \\
\hline & 40 & & 40 \\
\hline & 60 & & - \\
\hline & 80 & & 80 \\
\hline \multirow{5}{*}{30} & 0 & \multirow{5}{*}{30} & 0 \\
\hline & 20 & & - \\
\hline & 40 & & 40 \\
\hline & 60 & & - \\
\hline & 80 & & 80 \\
\hline \multirow{5}{*}{45} & 0 & \multirow{5}{*}{45} & 0 \\
\hline & 20 & & - \\
\hline & 40 & & 40 \\
\hline & 60 & & - \\
\hline & 80 & & 80 \\
\hline
\end{tabular}

of urea $(45 \% \mathrm{~N})$. Sowing, at a density of 330 seeds $\mathrm{m}^{-2}$, was performed on June 14 (2017) and June 9 (2018), in soybean crop residue.

Before sowing, the area was desiccated with glyphosate (3 $\mathrm{L} \mathrm{ha}^{-1}$ ) and paraquat (1.5 $\mathrm{L} \mathrm{ha}^{-1}$ ) herbicides. For disease control, applications of the fungicides based on bixafem, prothioconazole and trifloxystrobin $\left(0.5 \quad \mathrm{~L} \quad \mathrm{ha}^{-1}\right)$ and pyraclostrobin and metconazole were done $\left(0.75 \mathrm{~L} \mathrm{ha}^{-1}\right)$ (Reunião, 2017).

\section{Variables evaluated}

Quantification of canopy reflectance with the Greenseeker hand-held sensor

The reflectance of the vegetative canopy was measured using the Greenseeker ${ }^{\circledR}$ sensor, which provides the value of Normalized Difference Vegetation Index (NDVI) (Rouse et al., 1974). The equipment was positioned parallel to the crop rows, at a height ranging from 0.8 to $1.0 \mathrm{~m}$ above the top of the canopy. The readings were taken by the linear displacement of the equipment over the experimental unit. Data collection started at crop emergence and was carried out until grain filling.

\section{Aboveground dry biomass yield and $\mathrm{N}$ content}

At the phenological stage of six fully expanded leaves and full flowering (2017 and 2018 seasons), wheat plants were collected in a $0.25 \mathrm{~m}^{2}$ area in each plot. The samples were oven-dried and then weighed to quantify to quantify the aboveground dry biomass. For the evaluation of $\mathrm{N}$ content, the samples were ground and analyzed by the Kjeldahl method (Tedesco et al., 1995).

\section{Grain yield}

The useful area of the plot was harvested, corresponding to the eight central rows of each plot. Then, the weight of grains per experimental unit was quantified and the value extrapolated to grain yield, in $\mathrm{kg} \mathrm{ha}^{-1}$ (13\% humidity on wet basis).

\section{Statistical analysis}

The data were submitted to descriptive statistical analysis, analysis of variance, and multiple comparison test of means by Tukey Test $(p<0.05)$. For the quantitative variables, Pearson's linear correlation analysis was performed.

\section{Results and Discussion}

There was a statistically significant difference between treatments, for both years, in both cultivars, for grain yield (Figure 2). The treatment that obtained the highest grain yield, for both cultivars in both years, was $45 \mathrm{~kg} \mathrm{ha}^{-1}$ of base $\mathrm{N}$ plus $80 \mathrm{~kg} \mathrm{ha}^{-1}$ of $\mathrm{N}$ in topdressing, totaling a dose of $125 \mathrm{~kg}$ $\mathrm{ha}^{-1}$ of $\mathrm{N}$. Fertilizer recommendations for wheat are 15 to 20 $\mathrm{kg} \mathrm{ha}^{-1}$ of $\mathrm{N}$ in the base and $80 \mathrm{~kg} \mathrm{ha}^{-1}$ of $\mathrm{N}$ in the top dressing, under growing conditions similar to those found in the study (CQFS - RS/SC, 2018).

The application of nitrogen fertilizer, for both years, occurred between late July and early August (fully expanded six-leaf stage). It can be observed that in the year 2017, air temperatures were higher and rainfall was lower than in 2018 (Figure 1). When nitrogen fertilization combined with irrigation is used, it is observed that with the increase in the volume of water applied, grain yield and $\mathrm{N}$ accumulation in wheat grain increase (Mon et al., 2016). Thus, the uptake and assimilation of $\mathrm{N}$ by the plants may have had an effect between years, reflecting on grain yield, and aboveground biomass.

When analyzing different levels of nitrogen fertilization, also for the wheat crop, Corassa et al. (2018) observed that the highest dose of $\mathrm{N}$ applied, i.e., the combination of 70 $\mathrm{kg} \mathrm{N}$ ha-1 at sowing and $23 \mathrm{~kg} \mathrm{~N} \mathrm{ha}^{-1}$ at ear emergence, did not differ statistically from the dose of $70 \mathrm{~kg} \mathrm{~N} \mathrm{ha}^{-1}$, applied only at sowing, in the homogeneous region of adaptation of wheat cultivars I of Rio Grande do Sul state. The area where the authors conducted the experiment had organic matter contents higher than $3 \%$. Different soil and climate conditions present a maximum $\mathrm{N}$ dose for grain yield, which was not observed in the present study, since the highest doses represented the highest grain yields.

For aboveground biomass at the phenological stage of the sixth fully expanded leaf (Figure 3), where the plants had only received fertilizer at sowing, the dose that reached the highest levels of dry mass were 30 and $45 \mathrm{~kg} \mathrm{~N} \mathrm{ha}^{-1}$, for both cultivars, in the two years evaluated. At the beginning of development, after using the seed reserve, plants need nutrients to continue their development. $\mathrm{N}$ is an essential macronutrient for the formation of the chlorophyll molecule, and for the production of several metabolic components that are essential for cell multiplication and metabolism. 
2017
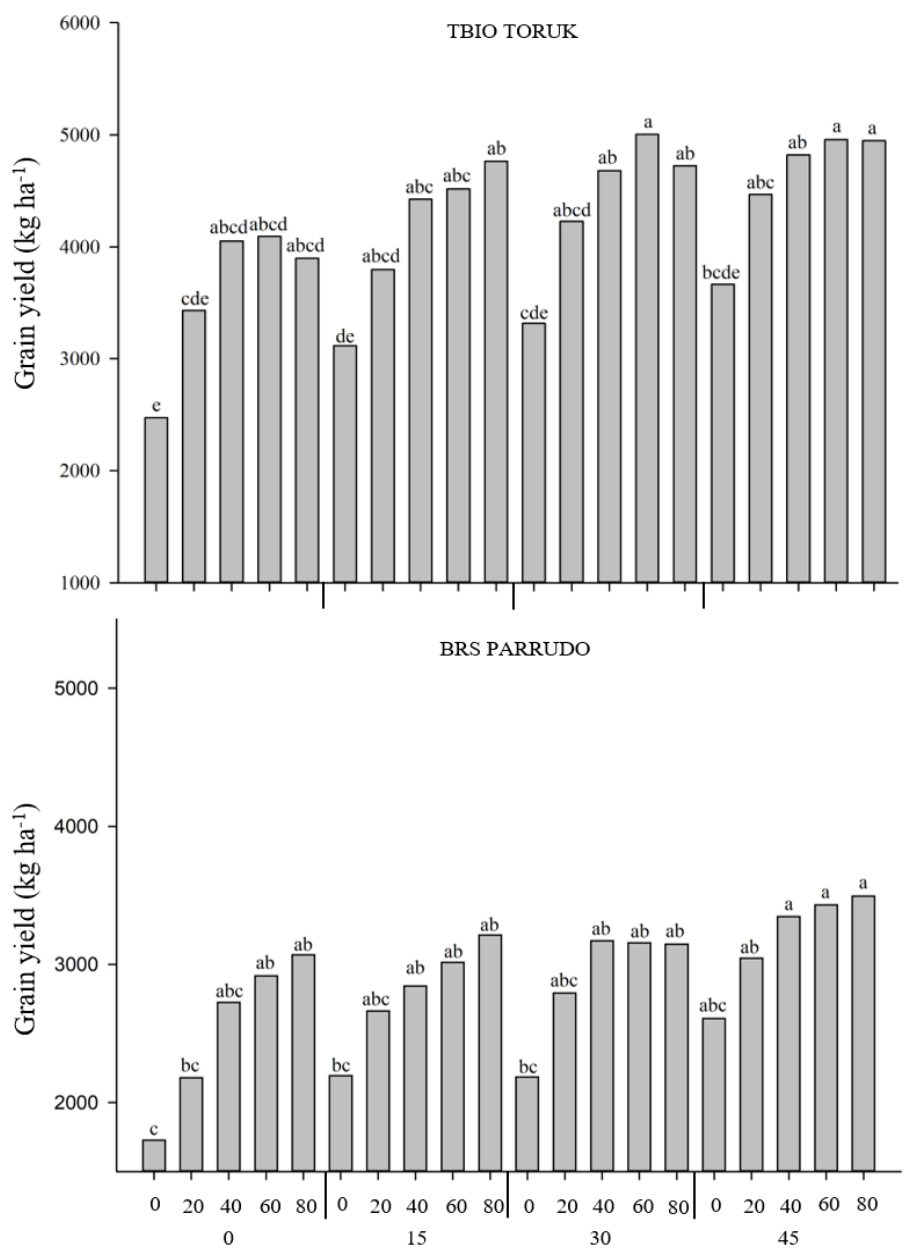

Treatments ( $\mathrm{N}$ dose at plant emergence and in topdressing $\left(\mathrm{kg} \mathrm{ha}^{-1}\right)$
2018
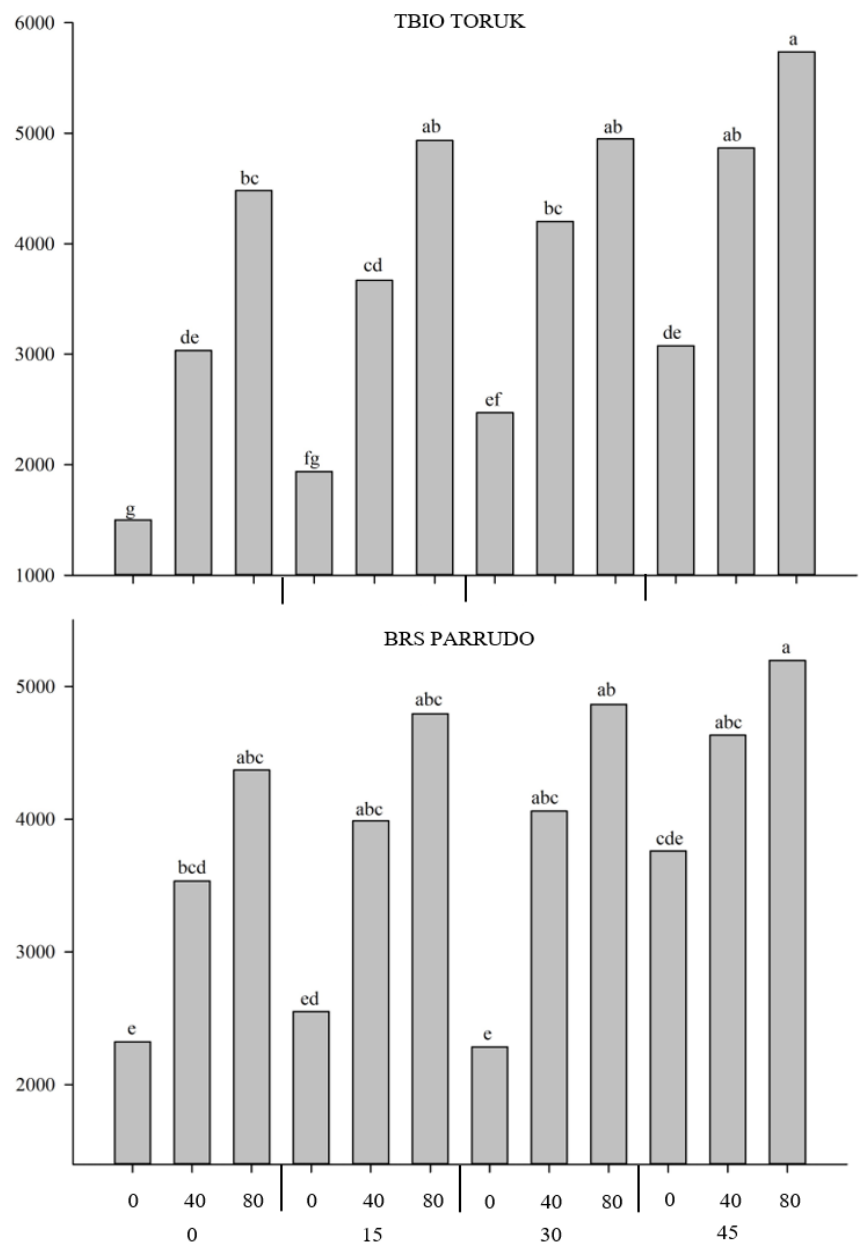

Treatments $\left(\mathrm{N}\right.$ dose at plant emergence and in topdressing $\left(\mathrm{kg} \mathrm{ha}^{-1}\right)$ Averages followed by the same letter, within each cultivar, do not differ by Tukey test ( $p \geq 0.05)$.

Figure 2. Grain yield of wheat cultivars BRS Parrudo and TBIO Toruk, in 2017 and 2018, as a function of base and top dressing $\mathrm{N}$ doses.

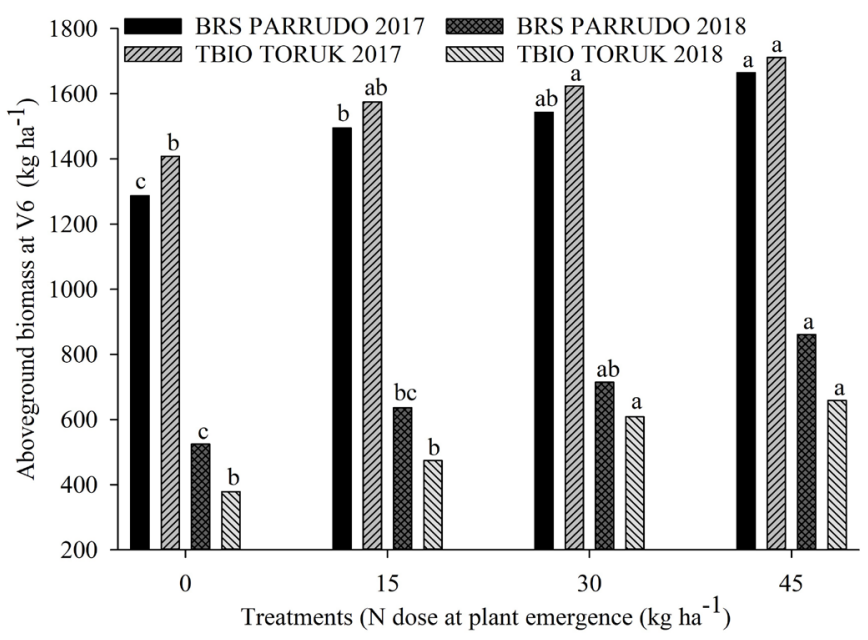

Averages followed by the same letter, within each cultivar and year, do not differ by Tukey test $(p \geq 0.05)$.

Figure 3. Biomass productivity at the phenological stage of six fully expanded leaves (V6) as a function of nitrogen (N) doses applied at plant emergence, for wheat cultivars BRS Parrudo and TBIO Toruk, in 2017 and 2018.
It can be seen that in 2017, for both cultivars, the biomass production was higher, in absolute values, than in the year 2018. The higher rainfall and lower air temperatures, compared to the previous season (Figure 1), may have influenced the germination and initial establishment of the crop, causing the difference in biomass production (Figure 3 ).

In the assessments of aboveground biomass at the flowering stage, the 2018 season showed higher averages compared to 2017 (Figure 4). This difference is linked to the lower temperatures, which occurred during the second season (Figure 1). The optimum temperatures for the development of the wheat crop are approximately 18 to $24{ }^{\circ} \mathrm{C}$ (Jacott \& Boden, 2020). However, small temperature fluctuations can cause differences in biomass yield and grain yield. The highest average biomass yields at wheat flowering, for the cultivar TBIO Toruk, were achieved by the treatments of 15 and $30 \mathrm{~kg} \mathrm{~N} \mathrm{ha}^{-1}$ at sowing and $80 \mathrm{~kg} \mathrm{~N} \mathrm{ha}^{-1}$ in top dressing. On the other hand, those that did not receive nitrogen fertilization, excluding only the dose of $15 \mathrm{~kg} \mathrm{~N} \mathrm{ha}^{-1}$ in the cultivar BRS Parrudo for the 2017 season, were the ones with the lowest averages. 
2017
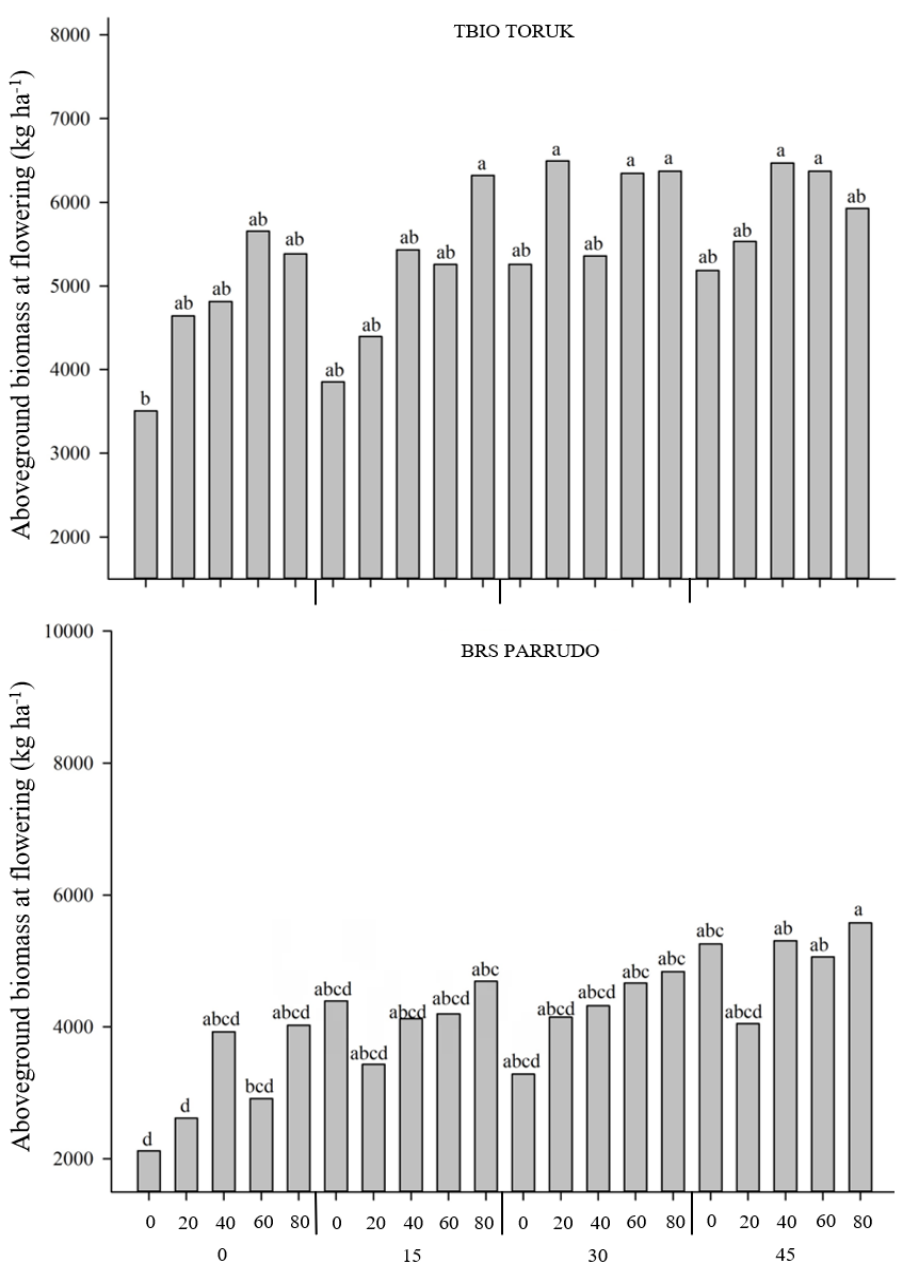

Treatments $\left(\mathrm{N}\right.$ dose at plant emergence and in topdressing $\left(\mathrm{kg} \mathrm{ha}^{-1}\right)$
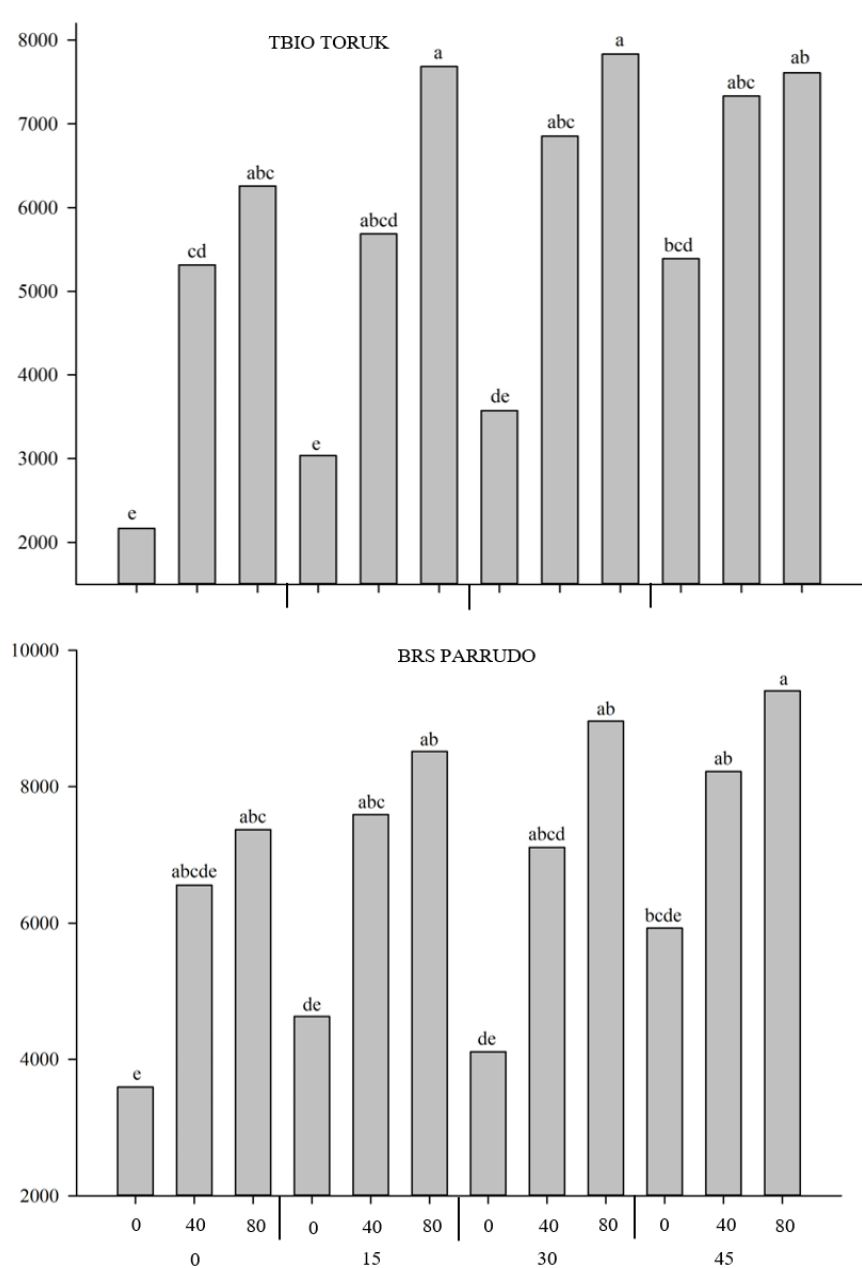

Treatments $\left(\mathrm{N}\right.$ dose at plant emergence and in topdressing $\left(\mathrm{kg} \mathrm{ha}^{-1}\right)$

Averages followed by the same letter, within each cultivar, do not differ by Tukey test ( $p \geq 0.05$ ).

Figure 4. Aboveground biomass yield at the phenological stage of flowering, for the wheat cultivars BRS Parrudo and TBIO Toruk, in 2017 and 2018, as a function of $\mathrm{N}$ doses applied at plant emergence and in topdressing.

One way to assess both the biomass production and grain yield of a plant canopy, in a non-destructive manner, is to use vegetation indices. When analyzing the correlation between biomass at flowering, nitrogen content and grain yield with the value of Normalized Difference Vegetation Index (NDVI), it was found that from the phenological stage of second visible node in 2017 (Table 2), this correlated strongly with biomass at flowering and with grain yield, where values higher than 0.8 were found at the seventh fully expanded leaf (V7) stage for the TBIO Toruk cultivar, and at the booting stage in the BRS Parrudo cultivar. The $\mathrm{N}$ content of aboveground biomass is important because it is related to changes in carbon allocation between stem and ears, and also between structural carbon (Hoogmoed \& Sandras, 2018). The correlations of the variables

Table 2. Pearson linear correlation analysis for the variables NDVI, biomass at flowering (BF), nitrogen content (\% $\mathrm{N}$ flowering) and grain yield, in 2017.

\begin{tabular}{|c|c|c|c|c|c|c|}
\hline \multirow[b]{2}{*}{$\begin{array}{l}\text { Development } \\
\text { stage }\end{array}$} & \multicolumn{2}{|c|}{ Biomass at flowering } & \multicolumn{2}{|c|}{ Nitrogen content } & \multicolumn{2}{|c|}{ Grain yield } \\
\hline & $\begin{array}{l}\text { TBIO } \\
\text { Toruk }\end{array}$ & $\begin{array}{c}\text { BRS } \\
\text { Parrudo }\end{array}$ & $\begin{array}{l}\text { TBIO } \\
\text { Toruk }\end{array}$ & $\begin{array}{c}\text { BRS } \\
\text { Parrudo }\end{array}$ & $\begin{array}{l}\text { TBIO } \\
\text { Toruk }\end{array}$ & $\begin{array}{c}\text { BRS } \\
\text { Parrudo }\end{array}$ \\
\hline NDVI - V6 & $0.67^{*}$ & $0.77^{*}$ & 0.19 & -0.18 & $0.63^{*}$ & $0.50^{*}$ \\
\hline NDVI $-2^{\text {nd }}$ Node & $0.87^{*}$ & $0.83^{*}$ & $0.56^{*}$ & $0.47 *$ & $0.92 *$ & $0.96 *$ \\
\hline NDVI - Booting & $0.83^{*}$ & $0.65^{*}$ & $0.62 *$ & $0.63^{*}$ & $0.92 *$ & $0.95^{*}$ \\
\hline $\mathrm{N}$ (\% in tissue) & . & . & . & . & $0.61^{*}$ & $0.58^{*}$ \\
\hline
\end{tabular}

Correlation coefficients followed by * were significant at 5\%. V6 (Haun, 1973): phenological stage of sixth fully expanded leaf and seventh leaf not expanded; V7 (Haun, 1973): seventh fully expanded leaf stage; $2^{\text {nd }}$ Node, phenological stage of second node visible; BF: biomass at flowering; N: nitrogen in tissue (\%), at flowering. 
Table 3. Pearson linear correlation analysis for the variables NDVI, biomass at flowering (BF), nitrogen content (\% $\mathrm{N}$ flowering) and grain yield, in 2018.

\begin{tabular}{|c|c|c|c|c|c|c|}
\hline \multirow{2}{*}{$\begin{array}{l}\text { Development } \\
\text { stages }\end{array}$} & \multicolumn{2}{|c|}{ Biomass at flowering } & \multicolumn{2}{|c|}{ Nitrogen content } & \multicolumn{2}{|c|}{ Grain yield } \\
\hline & $\begin{array}{l}\text { TBIO } \\
\text { Toruk }\end{array}$ & $\begin{array}{c}\text { BRS } \\
\text { Parrudo }\end{array}$ & $\begin{array}{l}\text { TBIO } \\
\text { Toruk }\end{array}$ & $\begin{array}{c}\text { BRS } \\
\text { Parrudo }\end{array}$ & $\begin{array}{l}\text { TBIO } \\
\text { Toruk } \\
\end{array}$ & $\begin{array}{c}\text { BRS } \\
\text { Parrudo }\end{array}$ \\
\hline NDVI - $2^{\text {nd }}$ Node & $0.96 *$ & $0.93 *$ & 0.43 & $0.85^{*}$ & $0.95 *$ & $0.93^{*}$ \\
\hline NDVI - $3^{\text {rd }}$ Node & $0.97 *$ & $0.94^{*}$ & 0.55 & $0.88^{*}$ & $0.97 *$ & $0.95^{*}$ \\
\hline NDVI - Booting & $0.96 *$ & $0.94 *$ & $0.60 *$ & $0.82^{*}$ & $0.94 *$ & $0.95^{*}$ \\
\hline NDVI - Heading & $0.96 *$ & $0.94^{*}$ & $0.63^{*}$ & $0.86 *$ & $0.94 *$ & $0.95^{*}$ \\
\hline NDVI - Flowering & $0.95 *$ & $0.93 *$ & $0.63^{*}$ & $0.78^{*}$ & $0.97 *$ & $0.94^{*}$ \\
\hline $\mathrm{BF}\left(\mathrm{kg} \mathrm{ha}^{-1}\right)$ & . & . & 0.48 & $0.79 *$ & $0.97 *$ & $0.98^{*}$ \\
\hline $\mathrm{N}$ (\% in tissue) & . & . & . & . & 0.47 & $0.86^{*}$ \\
\hline
\end{tabular}

Correlation coefficients followed by * were significant at $5 \% .2^{\text {nd }}$ Node: phenological stage of second node visible (Haun, 1973); BF: biomass at flowering; $\mathrm{N}$ : nitrogen in tissue (\%), at flowering.

with biomass at the sixth fully expanded leaf stage (V6) were not significant for the two cultivars, in both years.

In the NDVI evaluations at the grain filling stage the correlations with grain yield, for both cultivars, was higher than 0.9, which is characterized as high correlation. These results are important, because they help in estimating the yield of the wheat crop from this index.

The correlation coefficient between vegetation indices and biomass at flowering were also high in 2018 (Table 3). With the exception of the flowering stage, the coefficients were greater than 0.9 . There is also a very high correlation between biomass at flowering and grain yield, for both cultivars.

The high correlation coefficients found for both years and cultivars mean that there is a strong relationship between the variables analyzed, with the possibility of helping in the decision making process and in the estimation of wheat grain yields.

\section{Conclusions}

The increase in $\mathrm{N}$ doses contributes to the increase in biomass productivity and consequently, in grain yield, for the cultivars TBIO Toruk and BRS Parrudo. The doses that were most efficient in increasing both biomass and grain yield were the doses of 30 and $45 \mathrm{~kg} \mathrm{ha}^{-1}$ of $\mathrm{N}$ at plant emergence and 80 $\mathrm{kg} \mathrm{ha}^{-1}$ of $\mathrm{N}$ in topdressing.

The estimation of biomass production and grain yield was highly correlated with the NDVI at all stages evaluated. Thus, the use of NDVI becomes versatile for real-time estimation of these variables.

\section{Compliance with Ethical Standards}

Author contributions: Conceptualization: $\mathrm{CT}, \mathrm{CB}$; Data curation: $C T, M A D, F L S$, ALV; Formal analysis: $C T, C B$; Funding acquisition: $C B, A L V, C T$; Investigation: $C T, C B, M A D, F L S$, $A L V$; Methodology: $C T, C B, A L V$; Project administration: $C T, C B$; Resources: $C T, C B, A L V$; Supervision: $C T, C B, A L V$; Validation: $\mathrm{CT}, \mathrm{CB}, \mathrm{ALV}$; Visualization: $\mathrm{CT}, \mathrm{CB}, \mathrm{ALV}$; Writing - original draft: $C T, C B$; Writing - review \& editing: $C T, C B$, MAD, FLS, ALV.
Conflict of interest: The authors declare that there are no conflicts of interest.

Financing source: Coordenação de Aperfeiçoamento de Pessoal de Nível Superior (CAPES), Fundação Agrisus, and Conselho Nacional de Desenvolvimento Científico e Tecnológico (CNPq).

\section{Literature Cited}

Bergamaschi, H.; Melo, R.W.; Guadagnin, M.R.; Cardoso, L.S.; Silva, M.I.G.; Comiran, F.; Dalsin, F.; Tessari, M.L.; Brauner, P.C. Clima da Estação Experimental da UFRGS e região de abrangência. Porto Alegre: UFRGS, 2003. 77p.

Bredemeier, C.; Mundstock, C.M. Estádios fenológicos do trigo para a adubação nitrogenada em cobertura. Revista Brasileira de Ciência Solo. v.25, n.2, p.317-323, 2001. https://doi.org/10.1590/S010006832001000200008

Comissão de Química e Fertilidade do Solo - CQFS - RS/SC. Manual de calagem e adubação para os Estados de Rio Grande do Sul e de Santa Catarina. Viçosa: Sociedade Brasileira de Ciência do Solo. 2018. 376 p.

Corassa, G.M.; Hansel, F.D.; Lollato, R.; Pires, J.L.F.; Schwalbert, R.; Amado, T.J.C.; Guarienti, E.M.; Gaviraghi, R.; Bisognin, M.B.; Reimche, G.B.; Santi, A.L.; Ciampitti, I.A.; Nitrogen management strategies to improve yield and dough properties in hard red spring wheat. Agronomy Journal. v. 110, n.6, p. 2417-2429, 2018. https://doi.org/10.2134/agronj2018.02.0075.

Dehnavi, A.R.; Zahedi, M.; Ludwiczak, A.; Perez, S.C.; Piernik, A. Effect of salinity on seed germination and seedling development of sorghum (Sorghum bicolor L. Moench) genotypes. Agronomy, v.10, n.6, e859, 2020. https://doi.org/10.3390/agronomy10060859.

Elsayed, S.; Barmeier, G.; Schmidhalter, U. Passive Reflectance Sensing and Digital Image Analysis Allows for Assessing the Biomass and Nitrogen Status of Wheat in Early and Late Tillering Stages. Frontiers Plant Science, v.9, e01478, 2018. https://doi. org/10.3389/fpls.2018.01478.

Finney, D.M.; White, C.M.; Kaye, J.P. Biomass production and carbon/ nitrogen ratio influence ecosystem services from cover crop mixtures. Organic agriculture and agroecology, v.108, n.1, p.3952, 2016. https://doi.org/10.2134/agronj15.0182.

Haun, J.R. Visual quantification of wheat development. Agronomy Journal, v.65, n.1, p.116-119, 1973. https://doi.org/10.2134/agr onj1973.00021962006500010035x. 
Heroldová, M.; Michalko, R.; Suchomel, J.; Zejda, J. Influence of notillage versus tillage system on common vole (Microtus arvalis) population density. Pest Management Science, v.74, n.6, p.13461350, 2017. https://doi.org/10.1002/ps.4809.

Hoogmoed, M.; Sandras, V.O. Water stress scatters nitrogen dilution curves in wheat. Frontiers in Plant Science, v.9, e406, 2018. https://doi.org/10.3389/fpls.2018.00406.

Instituto de Pesquisas Agronômicas - IPAGRO. Observações meteorológicas no estado do Rio Grande do Sul. Porto Alegre: IPAGRO, 1979. 271p. (IPAGRO. Boletim Técnico, 3).

Jacott, C.N.; Boden, S.A. Feeling the heat: developmental and molecular responses of wheat and barley to high ambient temperatures. Journal of Experimental Botany, v.71, n.19, p.5740-5751, 2020. https://doi.org/10.1093/jxb/eraa326.

Kuhn, N.J.; Hu, Y.; Bloemertz, L.; He, J.; Li, H.; Greenwood, P. Conservation tillage and sustainable intensification of agriculture: regional vs. global benefit analysis. Agriculture, Ecosystems \& Environment, v.216, p. 155-165, 2016. https://doi.org/10.1016/j. agee.2015.10.001.

Leghari, S.J. Wahocho, N.A.; Laghari, G.M.; Hafeezlaghari, A.; Mustafabhabhan, G.; Hussaintalpu, K. Role of nitrogen for plant growth and development: a review. Advances in Environmental Biology, v.10, n.9, p.209-218, 2016. http://www.aensiweb.net/ AENSIWEB/aeb/aeb/2016/September/209-218.pdf. 05 Nov. 2020.
Lu, D.; Yue, S.; Lu, F.; Cui, Z.; Liu, Z.; Zou, C.; Chen, X. Integrated crop-N system management to establish high wheat yield population. Field Crops Research, v. 191, p. 66-74, 2016. https://doi.org/10.1016/j. fcr.2016.02.015.

Mon, J. Bronson, K.F.; Hunsaker, D.J.; Thorp, K.R.; White, J.W.; French, A.N. Interactive effects of nitrogen fertilization and irrigation on grain yield, canopy temperature, and nitrogen use efficiency in over head sprinklerirrigated durum wheat. Field Crops Research, v.191, p.54-65, 2016. https://doi.org/10.1016/j.fcr. 2016.02.011.

Reunião da Comissão Brasileira de Pesquisa de Trigo e Triticale. Informações técnicas para trigo e triticale - safra 2017. Brasília: Embrapa, 2017. $240 \mathrm{p}$.

Rouse, J.W.; Haas, R.H.; Schell, J.A.; Deering, D.W. Monitoring vegetation systems in the Great Plains with ERTS. In: Earth Resources Technology Satellite-1 Symposium, 3., 1974, Greenbelt. Proceedings... Greenbelt: NASA, 1974. v.1, section A, p. 309-317. https://ntrs.nasa.gov/api/ citations/19740022614/downloads/19740022614.pdf. 05 Nov. 2020.

Streck, E. V.; Kämpf, N.; Dalmolin, R. S. D.; Klamt, E.; Nascimento, P. C. do; Giasson, E.; Pinto, L. F. S. Solos do Rio Grande do Sul. Porto Alegre: UFRGS; EMATER/RS-ASCAR, 2018. 251 p.

Tedesco, M. J.; Gianello, C.; Bissani, C. A.; Bohnen, H.; Volkweiss, S. J. Análise de solo, plantas e outros materiais. 2.ed. Porto Alegre: UFRGS; Departamento de Solos, 1995. 174p. 1995. (UFRGS. Boletim técnico, 5).

Zörb, C.; Ludewig, U.; Hawkesford, M.J. Perspective on wheat yield and quality with reduced nitrogen supply. Trends in Plant Science, v.23, n.11, p.1029-1037, 2018. https://doi.org/10.1016/j.tplants.2018.08.012. 